\section{Ex-vivo Effect of Intracanal Medications Based on Ozone and Calcium Hydroxide in Root Canals Contaminated with Enterococcusfaecalis}

Roberta Vieira Farac ${ }^{1}$, Antonio Carlos Pizzolitto², Juliane Maria Guerreiro Tanomaru1, Renata Dornelles Morgental ${ }^{3}$, Regina Karla de Pontes Lima, Idomeo Bonetti-Filho ${ }^{1}$

This ex vivo study evaluated the antibacterial effect of intracanal medications in root canals contaminated with Enterococcus faecalis. Fifty single-rooted human teeth were contaminated with E. faecalis (ATCC 29212) and incubated at $37^{\circ} \mathrm{C}$ for 21 days. The specimens were randomly divided into 5 groups according to the intracanal medication used: OZ-PG: ozonized propylene glycol; $\mathrm{CH} / \mathrm{CPMC}$ : calcium hydroxide/camphorated paramonochlorophenol; $\mathrm{OZ}-\mathrm{PG} / \mathrm{CH}$ ozonized $\mathrm{PG} / \mathrm{CH}$; $\mathrm{PC}$ : positive control group (no medication); and NC: negative control group (no contamination). The samples were collected after 7 days (post-medication) and 14 days (final). Bacterial growth was checked by counting the colony-forming units (CFU). OZ-PG and $\mathrm{CH} / \mathrm{CPMC}$ reduced significantly the CFU counts compared with PC in the post-medication and final samples, with no statistically significant differences among them. On the other hand, 0Z-PG/CH did not reduce significantly the number of bacteria compared with $\mathrm{PC}$. In conclusion, among the evaluated medications $\mathrm{OZ}-\mathrm{PG}$ and $\mathrm{CH} / \mathrm{CPMC}$ were the most effective against $E$. faecalis.

\author{
'Department of Restorative \\ Dentistry, Araraquara Dental \\ School, UNESP - Univ Estadual \\ Paulista, Araraquara, SP, Brazil \\ ${ }^{2}$ Department of Clinical Analysis, \\ Araraquara School of Pharmaceutical \\ Sciences, UNESP - Univ Estadual \\ Paulista, Araraquara, SP, Brazil \\ ${ }^{3}$ Department of Endodontics, \\ Dental School, PUCRS - Pontifical \\ Catholic University of Rio Grande \\ do Sul, Porto Alegre, RS, Brazil
}

Correspondence: Renata Dornelles Morgental, Avenida Itaqui, 71/201, 90460-140 Porto Alegre, RS, Brasil. Tel: +55-51-3331-8204. e-mail: remorgental@hotmail.com

Key Words: calcium hydroxide, Endodontics, Enterococcus faecalis, ozone, root canal preparation.

\section{Introduction}

Resistant microorganisms may remain inside the root canals after biomechanical preparation, or even penetrate in the root canal system during or after the endodontic treatment. These microorganisms and their byproducts are able to promote persistent or secondary infections, leading to treatment failure. In these situations, the root canal microbiota is composed of fewer species than primary infections and Gram-positive bacteria predominate (1).

E. faecalis has high prevalence in root-filled teeth associated with periapical lesions and shows resistance against many antimicrobial agents. It possesses several virulence factors that contribute to its ability of surviving the effects of conventional root canal therapy (2). Additionally, this Gram-positive facultative anaerobe is able to invade dentine tubules and bind to collagen (3).

Among other applications in endodontics, calcium hydroxide $(\mathrm{CH})$ is widely accepted as an interappointment medication during root canal treatment $(4,5)$. However, this alkaline product is not able to kill all microbial species, especially $E$. faecalis (6). The combination of $\mathrm{CH}$ with camphorated paramonochlorophenol (CPMC) increases its antimicrobial activity $(7,8)$. Nevertheless, CPMC is a potential irritant to vital tissues and it should be used with caution (9).

Ozone presents interesting biologic characteristics because it is a very reactive gas, which produces oxidizing radicals in presence of water. They penetrate and attack the cell membranes, disturbing the osmotic equilibrium, allowing the oxidation of amino acids and fatty acids, which may cause cell lyses. This antimicrobial property has been used in the treatment of several diseases that involve bacteria, yeasts and virus (10).

The use of ozone in dentistry is still not very widespread, but it has attracted the interest of some researchers. This gas has been proven effective against several microbial species found in the oral cavity, and as a method of disinfecting dentures (11). In Endodontics, studies have focused on the use of ozone as an irrigating agent or an intracanal medication (4,12-15). Despite pioneering applications of ozone in Endodontics (16), no consensus has yet been reached about the experimental results (17). The purpose of this study was to evaluate the antibacterial effect of intracanal medications based on ozone and $\mathrm{CH}$ in root canals contaminated with $E$. faecalis.

\section{Material and Methods}

The study protocol was approved by the institutional Ethics Committee (Process \#42/8). Fifty freshly extracted single-rooted teeth were used. They were previously radiographed in the mesiodistal plane and those with more than one root canal, with calcification, resorption or endodontic filling were excluded. Crowns were sectioned with a precision saw (Isomet 1000; Buehler Ltda, Lake 
Bluff, IL, USA) and the root lengths were standardized to approximately $15 \mathrm{~mm}$.

The root canals were enlarged $1 \mathrm{~mm}$ short of the root apex $(14 \mathrm{~mm})$ up to a size $50 \mathrm{~K}$-file (DentsplyMaillefer, Ballaigues, Switzerland) using the classic technique. Irrigation was performed with $1 \% \mathrm{NaOCl}$. After biomechanical preparation, the root canals were filled with 17\% trisodium EDTA (Biodinâmica, lbiporã, PR, Brazil), agitated with a size $50 \mathrm{~K}$-file for $3 \mathrm{~min}$, and then irrigated with $5 \mathrm{~mL}$ of saline to wash out the $\mathrm{NaOCl}$ and EDTA. The root apices were then sealed with composite resin (Z100; 3M, Sumaré, SP, Brazil) and all external root surfaces were made impermeable with epoxy adhesive (Araldite; Brascola, São Bernardo do Campo, SP, Brazil), except for the cervical access.

The specimens were randomly divided into five 24-well cell culture microplates (Corning Inc., Corning, NY, USA). Specimens were attached to the wells with acrylic resin (Clássico, São Paulo, SP, Brazil) and sterilized by gamma rays from a cobalt 60 source (Embrarad, Cotia, SP, Brazil).

The microbiological procedures were performed under aseptic conditions, in a laminar flow chamber. E. faecalis (ATCC 29212) was previously cultivated in Brain Heart ¿ Infusion broth (BHI; Difco, Detroit, MI, USA) at $37^{\circ} \mathrm{C}$ for $24 \mathrm{~h}$. A bacterial suspension was prepared with sterile saline solution to match the turbidity of $1.5 \times 10^{8} \mathrm{CFU} /$ $\mathrm{mL}$ (equivalent to $0.5 \mathrm{McF}$ arland standard). Then, $10 \mu \mathrm{L}$ of the bacterial suspension and $10 \mu \mathrm{L}$ of $\mathrm{BH}$ broth were inoculated into each root canal with the aid of an automatic micropipette (Gison, Villiers-le-Bel, France). The microplates containing the specimens were incubated at $37^{\circ} \mathrm{C}$ for 21 days. Throughout this period, BHI broth was added to the canals every 3 days. Six teeth did not receive bacterial suspension, only BHI broth (negative control group - NC).

Twenty-one days after inoculation, contamination was confirmed by seeding technique and CFU counting. This initial sample was performed using size 40 sterile paper points (Tanariman, Manacapuru, AM, Brazil) placed inside the root canal for $1 \mathrm{~min}$ and then transferred to test tubes containing $1 \mathrm{~mL}$ of sterile saline solution. The tubes were submitted to agitation for $1 \mathrm{~min}$ (Vortex Ap 56; Phoenix, Araraquara, SP, Brazil). After decimal serial dilutions, aliquots were seeded into Petri dishes containing $\mathrm{BHI}$ agar (Difco) and incubated at $37^{\circ} \mathrm{C}$ and $5 \% \mathrm{CO}_{2}$ for $24 \mathrm{~h}$. Bacterial growth was measured by the $\mathrm{CFU} / \mathrm{mL}$ counts of $E$. faecalis. Then, the root canals were dried with sterile paper points (Tanariman) and divided into three experimental and two control groups according to the used intracanal medications: OZPG ( $n=11)$ : ozonized propylene glycol; $\mathrm{CH} / \mathrm{CPMC}$ $(n=11)$ : commercial calcium hydroxide/camphorated paramonochlorophenol paste (Calen PMCC; SSWhite, Rio de Janeiro, RJ, Brazil); OZ-PG/CH ( $n=11) ; P C(n=11)$ : positive control group (contaminated teeth, without medication); and NC $(n=6)$ : negative control group (sterilized and noncontaminated teeth).

The propylene glycol vehicle (Labsynth, Diadema, SP, Brazil) was ozonized in $5 \mathrm{~mL}$ tubes submitted to ozone gas bubbles for $60 \mathrm{~min}$, using an ozone generator (C-20 Model; Ozonic, São Bernado do Campo, SP, Brazil), as proposed by Guinesi et al. (18). The ozonized product was disposed into empty anesthetic cartridges and taken to the root canals by a Carpule syringe and $27 \mathrm{G}$ needles. The powder/vehicle ratio used in the ozonized $\mathrm{PG} / \mathrm{CH}$ paste was the same as that employed in the commercial $\mathrm{CH} / \mathrm{CPMC}$ paste, which contains $48 \mathrm{~g} \% \mathrm{CH}$.

After 7 days, the root canals were irrigated with $5 \mathrm{~mL}$ of sterile saline solution and agitated with a size $50 \mathrm{~K}$-file up to the working length in order to remove the intracanal medication. The post-medication samples were collected as previously described. The number of $\mathrm{CFU} / \mathrm{mL}$ was calculated. Next, the specimens were filled with sterile saline and incubated for 7 more days. The final samples were collected and once again the number of $\mathrm{CFU} / \mathrm{mL}$ was determined.

Results were submitted to logarithmic transformation and analyzed using the BioEstat 5.0 (CNPq, Brasilia, DF, Brazil). Kruskal-Wallis and Dunn's tests were used for comparison among the groups. Friedman's test was used for comparison among the samples within each group. The significance level was set at 5\% for all analyses.

\section{Results}

Table 1 shows the recovery of pure $E$. faecalis strains from all teeth in the initial sample performed 21 days after incubation, which revealed similar $\mathrm{CFU} / \mathrm{mL}$ counts for all groups, except for the negative control.

After 7 days, in the post-medication samples, CH/CPMC had the lowest $\mathrm{CFU} / \mathrm{mL}$ counts. It was statistically similar to $\mathrm{OZ}-\mathrm{PG}$ and $\mathrm{NC}$, and different from the other groups.

Table 1. Bacterial counts ( $\mathrm{CFU} / \mathrm{mL} \log _{10}$ ) in the initial, post-medications and final samples

\begin{tabular}{lccc}
\hline Group & Initial & Post-medication & Final \\
\hline OZ-PG & $6.82 \pm 0.11 \mathrm{~A}, \mathrm{a}$ & $2.31 \pm 1.85 \mathrm{AB}, \mathrm{b}$ & $3.20 \pm 1.22 \mathrm{AB}, \mathrm{b}$ \\
$\mathrm{CH} / \mathrm{CPMC}$ & $6.90 \pm 0.10 \mathrm{~A}, \mathrm{a}$ & $0.62 \pm 1.41 \mathrm{~A}, \mathrm{~b}$ & $0.60 \pm 1.34 \mathrm{~A}, \mathrm{~b}$ \\
OZ-PG/CH & $6.89 \pm 0.14 \mathrm{~A}, \mathrm{a}$ & $3.80 \pm 1.34 \mathrm{BC}, \mathrm{b}$ & $4.14 \pm 0.35 \mathrm{~B}, \mathrm{~b}$ \\
Positive control & $6.78 \pm 0.38 \mathrm{~A}, \mathrm{a}$ & $4.68 \pm 0.25 \mathrm{C}, \mathrm{b}$ & $4.38 \pm 0.72 \mathrm{~B}, \mathrm{~b}$ \\
Negative control & $0 \pm 0 \mathrm{~B}, \mathrm{a}$ & $0 \pm 0 \mathrm{~A}, \mathrm{a}$ & $0 \pm 0 \mathrm{~A}, \mathrm{a}$ \\
\hline
\end{tabular}

OZ: ozonized. PG: propylene glycol. CH: calcium hydroxide. CPMC: camphorated paramonochlorophenol. Same uppercase letters in the same column and lowercase letters in the same row indicate statistically similar results $(p>0.05)$. 
The highest bacterial count was observed in $\mathrm{PC}$, without significant difference from OZ-PG/CH (Table 1).

After 14 days, in the final sample, $\mathrm{CH} / \mathrm{CPMC}$ had again the lowest CFU/mL counts. It was statistically similar to OZ$P G$ and the NC ( $p>0.05)$, and different ( $>>0.05)$ from the other groups. The highest bacterial count was observed in PC, without difference from OZ-PG and OZ-PG/CH (Table 1).

According to Friedman's test, all experimental groups and the positive control showed alterations in the bacterial counts throughout the procedures (Fig. 1). E. faecalis counts in the initial samples were significantly higher than in the post-medication and final samples, which were similar between themselves (Table 1). As expected, only NC did not show significant alterations throughout the procedures.

\section{Discussion}

Several methodologies can be used to assess the antimicrobial activity of endodontic medications. The experimental model adopted in this study allows simulating endodontic infection in the root canal system and dentinal tubules, closely resembling in vivo clinical situations (19).

E. faecalis was used for being frequently associated with post-endodontic therapy failure (2) and also because of its resistance to $\mathrm{CH}$-based intracanal dressings (20). A 21-day period of contamination was adopted because it allows diffusion of the E. faecalis suspension through the dentinal tubules, as reported by Cardoso et al. (17). Contamination methodology was confirmed by the recovery of pure $E$. faecalis strains from all teeth in the initial sample, except for NC.

The ex vivo effect of ozonized PG and ozonized PG/CH as intracanal medications was evaluated against $E$. faecalis, in comparison with $\mathrm{CH} / \mathrm{CPMC}$. The medications remained within the root canals for 7 days and another sample was collected. Finding an interappointment medication with suitable bactericidal effect within a short period of time

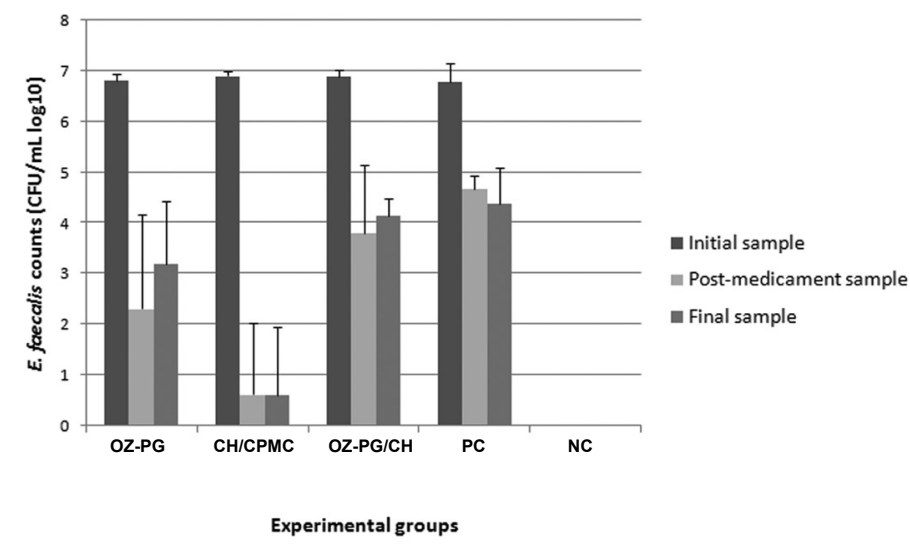

Figure 1. Chart showing the bacterial counts (CFU/mL $\log _{10}$ ) in the initial, postmedication and final samples. has been the focus of a current research worldwide.

In order to enhance the bacterial action of $\mathrm{CH}_{\text {, its }}$ combination with other antimicrobial agents, such as CPMC, has been proposed $(7,21,22)$. In the present study, a significant reduction in the bacterial counts was verified in the $\mathrm{CH} / \mathrm{CPMC}$ group, in agreement with previous studies. According to Siqueira and Lopes (23), the use of $\mathrm{CH}$ with CPMC extends the antibacterial spectrum and kills bacteria faster than the mixtures of $\mathrm{CH}$ with inert vehicles.

$\mathrm{CPMC}$ may complement the activity of $\mathrm{CH}$ by disrupting the bacterial cytoplasm membrane, denaturing proteins, and inactivating enzymes $(7,21)$. Furthermore, CPMC in combination with $\mathrm{CH}$ forms calcium p-chlorophenolate, which promotes controlled and extended release of calcium and hydroxyl ions (24).

Noetzel et al. (4) evaluated the efficacy of $\mathrm{CH}$, Er:YAG laser or gaseous ozone (either alone or combined with instrumentation and various irrigants) against $E$. faecalis in root canals. They verified that gaseous ozone applied directly into the root canals for $120 \mathrm{~s}$ had similar effect to $\mathrm{CH}$ paste applied for 7 days. In the present study, ozonized PG had similar effect to $\mathrm{CH} / \mathrm{CPMC}$ when both were applied for 7 days. However, the results of these investigations cannot be directly compared because the form and dose of ozone were different. Moreover, the present results show that ozonized $\mathrm{PG} / \mathrm{CH}$ had low effect against $E$. faecalis. There is no clear explanation for this finding, but the chemical interaction between ozone and $\mathrm{CH}$ probably affects the antimicrobial activity that these substances present separately. Further research addressing the chemical analysis of this combination is required.

While the half-life of ozone in gaseous form is ephemeral, its oil form allows storage for several months, avoiding the need of a generator (18). The mechanism of action of ozonized oils is related to their byproducts, the triozonides, which generate hydrogen peroxide and other compounds. The ozonized oil can be stored up to 2 years under refrigeration. It takes from $1 \mathrm{~h}$ to 2 days to reach the desirable concentration at room temperature. Overall, $1 \mathrm{~g}$ of oil can absorb $160 \mathrm{mg}$ of ozone (25).

In a previous research (13), ozonized oil was employed as an intracanal medication in dog's teeth, and the success rate was similar to that of $\mathrm{CH} / \mathrm{CPMC}$ and greater than the single-visit treatment group. The authors investigated the state of the periapical tissues using a histological score system. The vehicles of the pastes are not the same of the ones employed in the present study, but the results also show promising application of ozone in Endodontics.

In order to verify if the medications based on 
ozone have residual effect, microbiological samples were retrieved 14 days after the initial sample. The results were similar to those from the sample made 7 days postmedication for all experimental groups. Thus, there is no residual effect, indicating that microorganisms located inside dentinal tubules, lateral canals and apical deltas were not eliminated by any medication and they were able to re-colonize the main root canal.

In conclusion, ozonized $\mathrm{PG}$ and $\mathrm{CH} / \mathrm{CPMC}$ reduced significantly the bacterial counts in comparison with PC in the post-medication and final sample. On the other hand, OZ-PG/CH was similar to PC in these samples. Thus, among the medications evaluated in this study, OZ-PG and $\mathrm{CH} / \mathrm{CPMC}$ were the most effective against $E$. faecalis. These findings indicate a potential use of ozone as an intracanal medication. However, future studies evaluating biocompatibility, time of application and physicochemical properties should be performed to determine whether this substance is actually suitable for clinical use.

\section{Resumo}

Este estudo ex vivo avaliou o efeito antibacteriano de medicações intracanal em canais radiculares contaminados com Enterococcus faecalis. Cinquenta dentes humanos unirradiculares foram contaminados com $E$. faecalis (ATCC 29212) e incubados a $37^{\circ} \mathrm{C}$ durante 21 dias. Os espécimes foram aleatoriamente divididos em diferentes grupos de acordo com a medicação intracanal utilizada: PG-OZ: propilenoglicol ozonizado; $\mathrm{HCl}$ PMCC: hidróxido de cálcio/paramonoclorofenol canforado; PG-OZ/CH; $\mathrm{CP}$ : controle positivo (sem medicação); e $\mathrm{CN}$ : controle negativo (sem contaminação). As amostras foram coletadas após 7 dias (pós-medição) e 14 dias (final). 0 crescimento bacteriano foi verificado através da contagem das unidades formadoras de colônias (UFC). PG-OZ e HC/PMCC reduziram estatisticamente o número de bactérias quando comparados com o $\mathrm{CP}$ nas amostras pós-medição e final, sem diferenças estatisticas entre si. Por outro lado, $\mathrm{PG}-\mathrm{OZ} / \mathrm{HC}$ não reduziu significativamente o número de bactérias em comparação com o CP. Em conclusão, entre as medicações avaliadas, PG-OZ e HC/PMCC foram as mais eficazes contra E. faecalis.

\section{References}

1. Pinheiro ET, Gomes BPFA, Ferraz CCR, Sousa ELR, Teixeira FB, SouzaFilho JF. Microorganisms from canals of root-filled teeth with periapical lesions. Int Endod J 2003;36:1-11.

2. Stuart CH, Schwartz SA, Beeson TJ, Owatz CB. Enterococcus faecalis: its role in root canal treatment failure and current concepts in retreatment. J Endod 2006;32:93-98.

3. Love LM. Enterococcus faecalis - a mechanism for its role in endodontic failure. Int Endod J 2001;34:399-405.

4. Noetzel J, Nonhoff J, Bitter K, Wagner J, Neumann K, Kielbassa AM. Efficacy of calcium hydroxide, Er:YAG laser or gaseous ozone against Enterococcus faecalis in root canals. Am J Dent 2009;22:14-18.

5. Mohammadi Z, Dummer PM. Properties and applications of calcium hydroxide in endodontics and dental traumatology. Int Endod J 2011;44:697-730.

6. Turk BT, Sen BH, Ozturk T. In vitro antimicrobial activity of calcium hydroxide mixed with different vehicles against Enterococcus faecalis and Candida albicans. Oral Surg Oral Med Oral Pathol Oral Radiol
Endod 2009;108:297-301.

7. Sukawat C, Srisuwan TA. Comparison of the antimicrobial efficacy of three calcium hydroxide formulations on human dentin infected with Enterococcus faecalis. J Endod 2002;28:102-104.

8. Lana $P E$, Scelza MF, Silva $L E$, Mattos-Guaraldi $A L$, Hirata Júnior $R$. Antimicrobial activity of calcium hydroxide pastes on Enterococcus faecalis cultivated in root canal systems. Braz Dent J 2009;20:32-36.

9. Nelson Filho P, Silva LA, Leonardo MR, Utrilla LS, Figueiredo F. Connective tissue responses to calcium hydroxide-based root canal medicaments. Int Endod J 1999;32:303-311

10. Nogales CG, Ferrari PH, Kantorovich EO, Lage-Marques JL. Ozone therapy in medicine and dentistry. J Contemp Dent Pract 2008;9:75-84.

11. Oizumi M, Suzuki T, Uchida M, Furuya J, Okamoto Y. In vitro testing of a denture cleaning method using ozone. J Med Dent Sci 1998;45:135139.

12. Estrela C, Estrela CR, Decurcio DA, Hollanda AC, Silva JA. Antimicrobial efficacy of ozonated water, gaseous ozone, sodium hypochlorite and chlorhexidine in infected human root canals. Int Endod J 2007:40:8593.

13. Silveira AM, Lopes HP, Siqueira Jr JF, Macedo SB, Consolaro A. Periradicular repair after two-visit endodontic treatment using two different intracanal medications compared with single-visit endodontic treatment. Braz Dent J 2007;18:299-304.

14. Huth KC, Quirling M, Maier S, Kamereck K, Alkhayer M, Paschos E, et al.. Effectiveness of ozone against endodontopathogenic microorganisms in a root canal biofilm model. Int Endod J 2009;42:3-13.

15. Kuştarci A, Sümer Z, Altunbaş D, Koşum S. Bactericidal effect of KTP laser irradiation against Enterococcus faecalis compared with gaseous ozone: an ex vivo study. Oral Surg Oral Med Oral Pathol Oral Radiol Endod 2009;107:e73-e79.

16. Barandun $A$, Boitel RH. Thirteen years of experience with the Barandun irrigator and ozone. Oral Surg Oral Med Oral Pathol 1962;15:986-995.

17. Cardoso MG, Oliveira LD, Koga-Ito $C Y$, Jorge AO. Effectiveness of ozonated water on Candida albicans, Enterococcus faecalis and endotoxins in root canals. Oral Surg Oral Med Oral Pathol Oral Radiol Endod 2008;105:85-91.

18. Guinesi AS, Andolfatto C, Bonetti Filho I, Cardoso AA, Passaretti Filho J, Farac RV. Ozonized oils: a qualitative and quantitative analysis. Braz Dent J 2011;22:37-40.

19. Menezes MM, Valera MC, Jorge AOC, Koga-Ito CY, Camargo CHR, Mancini MNG. In vitro evaluation of the effectiveness of irrigants and intracanal medicaments on microorganisms within root canals. Int Endod J 2004;37:311-319.

20. Basrani $B$, Tjäderhane $L$, Santos JM, Pascon E, Grad H, Lawrence HP, et al.. Efficacy of chlorhexidine- and calcium hydroxide-containing medicaments against Enterococcus faecalis in vitro. Oral Surg Oral Med Oral Pathol Oral Radiol Endod 2003;96:618-624.

21. Siqueira JF Jr, Magalhães KM, Rôças IN. Bacterial reduction in infected root canals treated with $2.5 \% \mathrm{NaOCl}$ as an irrigant and calcium hydroxide/camphorated paramonochlorophenol paste as an intracanal dressing. J Endod 2007;33:667-672.

22. Oliveira JCM, Alves FRF, Uzeda M, Rôças IN, Siqueira Jr JF. Influence of serum and necrotic soft tissue on the antimicrobial effects of intracanal medicaments. Braz Dent J 2010;21:295-300.

23. Siqueira JF Jr, Lopes HP. Mechanisms of antimicrobial activity of calcium hydroxide: a critical review. Int Endod J 1999;32:361-369.

24. Camargo CHR, Bernardineli N, Valera MC, de Carvalho CA, de Oliveira $L D$, Menezes MM, et al.. Vehicle influence on calcium hydroxide pastes diffusion in human and bovine teeth. Dent Traumatol 2006;22:302306.

25. Bocci V. Ozone: a new medical drug. Dordrecht: Springer Publications; 2005. 